\title{
Review: Mountaineering
}

Source: The Geographical Journal, Vol. 22, No. 3 (Sep., 1903), p. 324

Published by: geographicalj

Stable URL: http://www.jstor.org/stable/1775204

Accessed: 25-06-2016 06:16 UTC

Your use of the JSTOR archive indicates your acceptance of the Terms \& Conditions of Use, available at

http://about.jstor.org/terms

JSTOR is a not-for-profit service that helps scholars, researchers, and students discover, use, and build upon a wide range of content in a trusted digital archive. We use information technology and tools to increase productivity and facilitate new forms of scholarship. For more information about JSTOR, please contact support@jstor.org.

The Royal Geographical Society (with the Institute of British Geographers), Wiley are collaborating with JSTOR to digitize, preserve and extend access to The Geographical Journal 


\section{GENERAL.}

Mountaineerinf.

'Hochtouren in den Alpen, Spanien, Nordafrika, Kalifornien und Mexiko.' Von Raimund Schäfer. Leipzig: J. J. Weber. 1903.

Dr. Schäfer is an ardent climber and a geologist as well as a doctor of medicine. His volume is very various in its contents. In the early chapters he recounts his alpine adventures, which include a night in the observatory on the summit of Mont Blanc. These are followed by some tourist's notes on Spain, and a glimpse at Morocco. The reader is then called on to leap the Atlantic, cross by the Canadian Pacific Railway to San Francisco, and return by Mexics. To the geographer the most interesting portion of the volume will be the account of the great Mexican volcanoes. Dr. Schä 'er climbed Popocatepetl, Orizabı, and Ixtaccihuatl, and gives interesting details as to their features and geology. He calls attention to the unequal melting of the snowfields under tropical skies which produce the conditions known in the Andes as "Nieves penitente,", a term the origin of which Dr. Schäfer misapprebejds. Sir M. Conway's observations* do not seem to have been taken account of in the explanation he offers of the phenomenon. The volume is well got up, and fully illustrated; some of the coloured plates from the author's sketches being exceptionally successful.

\section{THE MONTHLY RECORD.}

\section{THE SOCIETY.}

French Geographers at the R.G.S.-An excursion to this country having been arranged in connection with the Annual Congress of French Geographical Societies, held this year at Rouen, an invitation was sent by the Society to the members of the party to a luncheon to be held in their honour during the course of the visit. It was at once accepted, and Monday, August 10, fixed for the date of the reception. On that day a party of some ninety members of the Congress, including several ladies, arrived at the Society's house at 11.30 a.m., and was received, in the absence in Norway of the President, by Major Darwin and other members of the Society's Council and staff. Among the distinguished visitors were M. Zévort, rector of the Caen Academy and president of the Congress; M. Canonville Delys, president of the Société Normande de Géographie; Generals Guillet and Messonier; M. de Saint Arroman, representing the Ministry of Public Instruction; M. Monbrun, representing the Geographical Society of Oran and the Government of Algeria; M. Monflier, general secretary of the Congress; and M. Sarrazin, the historian of Normandy. After examining the various objects of interest at the Society's house, including manuscript maps by explorers, early editions of Ptolemy, and other old geographical works which had been laid out for their inspection, the visitors proceeded at 12.30 to lunch at Limmer's Hotel, where the chair was taken by Major

* 'Aconcagua and Tierra del Fuego,' pp. 55 et seqq. Reference may also be made to Dr. Hauthal's paper in the Rerista del Museo de la Plata, vol. x. (1902). 